\title{
Advanced Flue Gas Conditioning as a Retrofit Upgrade to Enhance PM Collection from Coal-fired Electric Utility Boilers
}

\author{
Quarterly Technical Report \\ Reporting Period: February - March, 2000
}

\author{
Principal Authors \\ C. Jean Bustard \\ Kenneth E. Baldrey \\ Richard Schlager
}

Submitted: April 2000

DOE Award: DE-FC26-00NT40755--01

ADA Environmental Solutions, LLC

8100 SouthPark Way, B-2

Littleton, Colorado 80120 


\section{DISCLAIMER}

This technical report was prepared with the support of the U.S. Department of Energy, under Award No. DE-FC26-00FT40755. However, any opinions, findings, conclusions, or recommendations expressed herein are those of the author(s) and do not necessarily reflect the views of the DOE.

This report was prepared as an account of work sponsored by an agency of the United States Government. Neither the United States government nor any agency thereof, nor any of their employees, makes any warranty, express or implied, or assumes any legal liability or responsibility for the accuracy, completeness, or usefulness of any information, apparatus, product, or process disclosed, or represents that its use would not infringe privately owned rights. Reference herein to any specific commercial product, process, or service by trade name trademark, manufacturer, or otherwise does not necessarily constitute or imply its endorsement, recommendation, or favoring by the United States Government or any agency thereof. The views and opinions of authors expressed herein do not necessarily state or reflect those of the United States Government or any agency thereof. 


\begin{abstract}
The U.S. Department of Energy and ADA Environmental Solutions has begun a project to develop commercial flue gas conditioning additives. The objective is to develop conditioning agents that can help improve particulate control performance of smaller or under-sized electrostatic precipitators on utility coal-fired boilers. The new chemicals will be used to control both the electrical resistivity and the adhesion or cohesivity of the flyash. There is a need to provide cost-effective and safer alternatives to traditional flue gas conditioning with $\mathrm{SO}_{3}$ and ammonia. Preliminary testing has identified a class of common deliquescent salts that effectively control flyash resistivity on a variety of coals. A method to evaluate cohesive properties of flyash in the laboratory has been selected and construction of an electrostatic tensiometer test fixture is underway. Preliminary selection of a variety of chemicals that will be screened for effect on flyash cohesion has been completed.
\end{abstract}




\section{TABLE OF CONTENTS}

INTRODUCTION $\ldots \ldots \ldots \ldots \ldots \ldots \ldots \ldots \ldots \ldots \ldots \ldots$

EXECUTIVE SUMMARY $\ldots \ldots \ldots \ldots \ldots \ldots \ldots \ldots \ldots \ldots$

EXPERIMENTAL ......................... 4

Additives Spray Chamber .............................. 4

Flyash Resistivity Test Method ........................ 7

Upgrade to Laboratory Test Fixtures . . . . . . . . . . . . . . . . 8

Cohesivity Test Methods $\ldots \ldots \ldots \ldots \ldots \ldots \ldots \ldots \ldots \ldots \ldots \ldots, 8$

RESULTS AND DISCUSSION $\ldots \ldots \ldots \ldots \ldots \ldots \ldots \ldots \ldots \ldots \ldots$

Flyash Resistivity ............................... 10

Selecting Candidate Additives . . . . . . . . . . . . . . . . . . 11

Theoretical Considerations . . . . . . . . . . . . . . . . . . . . . . 12

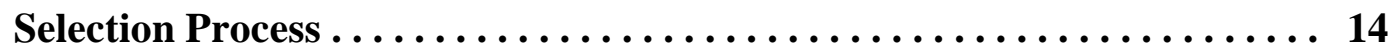

CONCLUSION $\ldots \ldots \ldots \ldots \ldots \ldots \ldots \ldots \ldots \ldots \ldots \ldots \ldots \ldots$

REFERENCES $\ldots \ldots \ldots \ldots \ldots \ldots \ldots \ldots \ldots \ldots \ldots \ldots \ldots \ldots \ldots$

LIST OF ACRONYMS AND ABBREVIATIONS ..........17 


\section{LIST OF GRAPHICAL MATERIALS}

\section{FIGURES}

Figure 1: Flyash Resistivity with Additive Chemicals "A" and "B" ........ 3

Figure 2: ADA-ES Additives Spray Chamber ................. 6

Figure 3: Effect of Moisture Loss on Flyash Resisitivity with Additive . . . . . . 11 Chemical "B"

\section{TABLES}

Table 1: ADA-ES Additives Spray Chamber Specifications ............. 4

Table 2: Cohesivity Test Methods ....................... 8 


\section{INTRODUCTION}

The objective of this program is to develop a family of cohesivity modifying flue gas conditioning agents that can be commercialized to provide utilities with a cost-effective means of complying with particulate emission and opacity regulations. Improving the cohesivity and agglomeration of flyash particles is a proven means of increasing the collection efficiency of an electrostatic precipitator (ESP). Optimizing these properties in combination with control of electrical resistivity is vital to the overall collection efficiency of ESPs, and flue gas conditioning may provide the most cost effective means in today's deregulated utility market for plants to meet DOE's goals of $0.01 \mathrm{lb} / \mathrm{Mbtu}$ and 99.99\% collection efficiency in the particle size 0.1 to 10 microns.

This new class of additives is needed because currently available agglomerating aids on the market require the storage and handling of large quantities of ammonia, which under recent legislation has been classified as extremely hazardous and necessitates extensive risk assessment and emergency response plans. There are also operating conditions and coals where the ammonia based technologies are not effective and treated ash may be unusable for recycle applications or difficult to dispose due to ammonia vapor off-gas.

This quarterly report covers technical work undertaken on the project from project inception to March 31, 2000. During this period work was underway on Task 1, Upgrade to Additives Test Fixture, and Task 2, Selection and Evaluation of Candidate Additives. Under Task 1, design and construction of a new flyash resistivity furnace was begun. Upgrades to ADA-ES Additives Spray Chamber were also begun. Under Task 2, laboratory resistivity testing of a family of deliquescent salts during the quarter is reported. Also, preliminary selection of candidate cohesivity chemicals for the upcoming laboratory trials was underway. 


\section{EXECUTIVE SUMMARY}

This project commenced in February 2000 as a joint effort between DOE and ADA Environmental Solutions. The objective is to develop commercial flue gas conditioning agents that can help improve performance of smaller or under-sized electrostatic precipitators on utility coal-fired boilers. Eastern plants that are increasingly switching to Powder River Basin coals are also candidates for retrofit flue gas conditioning. There is a need to provide cost-effective and safer alternatives to traditional flue gas conditioning with $\mathrm{SO}_{3}$ and ammonia. In particular, additives that can help control re-entrainment of collected flyash by increased adhesion or cohesivity of the flyash are the main target product.

There are numerous potential chemicals available that are applied to similar applications in other industries. However, surprisingly little research or development has been conducted on flyash cohesivity modifiers beyond the application of ammonia with $\mathrm{SO}_{3}$. One possible reason for this has been the lack of a suitable injection system for liquidbased chemicals. ADA-ES has developed over a period of years a commercial injection system specifically for liquid-based flue gas conditioning in utility flue gas ducts. This proven hardware together with ADA-ES background and experience in applying liquid flue gas conditioning will allow for a rapid development process of new FGC additives. Candidate additives can be taken directly from laboratory to full-scale with proven and existing hardware.

During this first quarter of the project, laboratory flyash resistivity of a class of common deliquescent salts was completed. These were evaluated as a "base" resistivitymodifying chemical to which the cohesivity chemicals can be combined. When applied to a common Powder River Basin flyash, these were found to be very effective resistivity modifiers, as seen in Figure 1. Both chemicals reduced flyash resistivity by more than two orders of magnitude. The additive-to-ash (ATA) weight ratio during these tests was approximately $0.5 \%$, which is substantially higher than will be required for full-scale application. Further tests were conducted on a low-sulfur sub-bituminous coal flyash with the same chemicals, with similar results. Based on this preliminary finding, both chemicals will be further evaluated at lower concentration and with eastern bituminous fly ashes. 


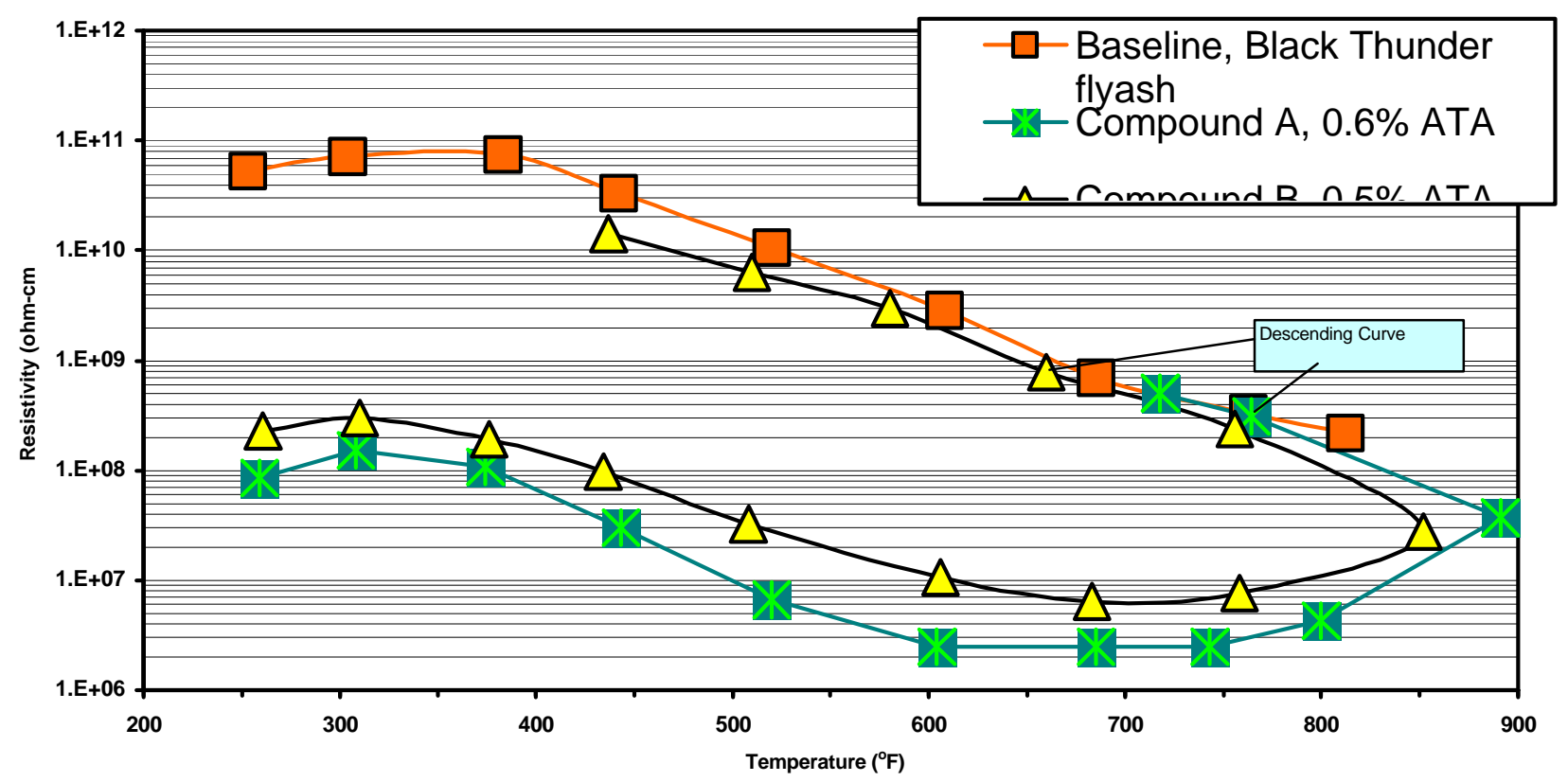

Figure 1: Flyash Resistivity with Additive Chemicals 'A' and 'B'

During the first quarter, a review of the available laboratory methods to evaluate flyash cohesivity was also undertaken. Several possible methods were investigated, including ring shear testing of tensile strength, various powder flowability tests, and an experimental "electrostatic tensiometer" that has been developed by Southern Research Institute. The electrostatic tensiometer measures tensile strength of a dust layer at the point of mechanical failure under increasing electrostatic stress. This method is conducted in an environmental chamber at temperature and humidity simulating an actual cold-side ESP. It is applicable to loose and uncompacted dusts and is therefore more useful than conventional ring shear powder testers that require compaction and sample preparation. For the purposes of this project it is ideal because it will allow a simple measurement of cohesion at conditions closely resembling a flyash layer on ESP plates. A laboratory test fixture based on this method will be constructed as part of Task 1.

Preliminary selection of classes of candidate cohesivity additives has begun. In the initial laboratory screening, the most widely available of each of several classes of chemicals will be evaluated. Chemicals that will be looked at include inherently sticky sugars and starches, various resins, adhesives, and binding compounds, moisturizers, hydrophilic "super-absorbent" polymers, inorganic hydrate-forming salts, high molecular weight organic polymers (commonly used for flocculation and viscosification), and watersoluble cellulose derivatives such as sodium carboxymethylcellulose. 


\section{EXPERIMENTAL}

\section{Additives Spray Chamber}

A key requirement of this project is a reliable laboratory method to condition flyash with chemical additives. The chemical must be introduced in a way that quantitatively simulates actual conditions in flue gas ducts. Temperature, spray droplet size, chemical concentration, flyash ash concentration, and chemical residence time in the gas stream must all be realistically simulated.

ADA-ES has an existing Additives Spray Chamber that has been used for flue gas conditioning research and development for the past several years. It is also currently used to conduct flyash resistivity tests of conditioned flyash. Experience with this equipment with numerous flyash types has shown that applying comparative results between flue gas conditioners to full-scale conditions is both possible and reliable. Table 1 lists design specifications for the chamber. Figure 2 shows the arrangement and the major components. In addition to the equipment shown, there is ancillary instrumentation that measures, regulates, and displays gas flow and temperatures throughout the system.

Table 1: ADA-ES Additives Spray Chamber Specifications

\begin{tabular}{|c|c|c|}
\hline Parameter & Typical Range & Remarks \\
\hline Chamber Dimensions & $\begin{array}{l}0.15 \text { m dia. x } 1.24 \text { m length } \\
\text { ( 6" dia. x 49" length) }\end{array}$ & \\
\hline Materials & 316 Stainless Steel & $\begin{array}{l}\text { High temperature seals and } \\
\text { insulation }\end{array}$ \\
\hline Gas Flow Rate & $\begin{array}{l}0.004-0.008 \text { cubic } \\
\text { meter/sec }(8-16 \text { acfm })\end{array}$ & \\
\hline Gas Composition & Humidified, ambient air & $\begin{array}{l}\mathrm{NH}_{3} \text { and } \mathrm{SO}_{3} \text { may be } \\
\text { injected for comparison }\end{array}$ \\
\hline $\begin{array}{l}\text { Chamber Residence Time } \\
\text { (from spray nozzle) }\end{array}$ & $1-5$ seconds & $\begin{array}{l}\text { Full-scale is typically } 0.5- \\
2 \text { seconds. }\end{array}$ \\
\hline Gas Temperature & $110-480^{\circ} \mathrm{C}\left(230-900^{\circ} \mathrm{F}\right)$ & $\begin{array}{l}\text { Electrical heating via in-line } \\
\text { and surface band heaters. }\end{array}$ \\
\hline Moisture Content & $8-20 \%$ by volume & $\begin{array}{l}\text { Moisture supplied by water } \\
\text { bath humidifier; } 10 \% \text { is } \\
\text { standard. }\end{array}$ \\
\hline Particulate Concentration & $\begin{array}{l}0.011-0.046 \mathrm{Kg} / \mathrm{cubic} \\
\text { meter }(5-20 \mathrm{gr} / \mathrm{acf})\end{array}$ & $\begin{array}{l}\text { Flyash metered from } \\
\text { mechanical screw feeder or } \\
\text { Arbo Vibrating Tray feeder. }\end{array}$ \\
\hline
\end{tabular}




\begin{tabular}{|l|l|l|}
\hline $\begin{array}{l}\text { Spray Droplet Size for dual- } \\
\text { fluid air/liquid atomizer }\end{array}$ & Dmax $<25$ microns dia. & $\begin{array}{l}\text { Nozzle manufacturer's } \\
\text { published data }\end{array}$ \\
\hline Liquid Injection Rate & $2-4 \mathrm{ml} . / \mathrm{min}$ & $\begin{array}{l}\text { Liquid feed rate monitored } \\
\text { gravimetrically }\end{array}$ \\
\hline Chemical Concentration & $1-2 \%$ by weight & $\begin{array}{l}\text { Filter compartment heated } \\
\text { to }>148^{\circ} \mathrm{C}\left(300^{\circ} \mathrm{F}\right)\end{array}$ \\
\hline Sample Collection & micron pomex bag filter, 25 & \\
\hline
\end{tabular}

In this test arrangement, flyash is entrained in a heated ambient air stream and then introduced to the spray chamber. A secondary, humidified air stream is also injected upstream of the spray chamber. The secondary air stream is humidified by passage through a heated water bath. The moisture content is controlled by regulation of the temperature of the water vapor over the heated bath and by the gas flow rate. Moisture content of the combined gas stream is typically maintained at $10 \%$ by volume, but can be adjusted as necessary.

The flue gas conditioning (FGC) additive chemical is prepared as an aqueous solution in de-ionized, distilled water. The solution is metered through a precision Peristaltic liquid pump and injected into the heated spray chamber through a dual-fluid (air/liquid) atomizing nozzle. The resulting spray is an extremely fine mist. The spray is directed in a co-current arrangement with the carrier gas and the entrained flyash particulate. The additive spray and the entrained flyash pass downward through the spray chamber and are then collected onto a heated Nomex fabric filter downstream of the spray chamber. The primary contact of additive and flyash is on the surface of the filter bag. Once a flyash coating begins to build on the filter the additive is intimately mixed into the filtered layer.

The Additive Spray Chamber surface heaters and associated zone temperature controllers are capable of maintaining gas temperatures above $480^{\circ} \mathrm{C}\left(900^{\circ} \mathrm{F}\right)$ or at whatever temperature is necessary to simulate the process stream. For cold-side ESP conditions, the gas temperature is typically controlled at $125-160^{\circ} \mathrm{C}\left(260-320^{\circ} \mathrm{F}\right)$. For each test series, the liquid injection rate, gas flow rate, humidity and gas temperature are maintained constant.

Once the collection phase of each run is completed, gas flow is discontinued, the Nomex filter is extracted, the flyash catch is weighed, and the additive chemical to ash weight ratio (additive-to-ash wt. \%, ATA) is determined. A sample layer of the conditioned flyash is then re-distributed onto a resistivity measurement cell located in a side recess of the spray chamber. The chamber is resealed and gas flow and humidity are reintroduced. After the sample ash layer has re-equilibrated with the gas stream, flyash resistivity is measured at various temperatures on an ascending curve, as described below. 


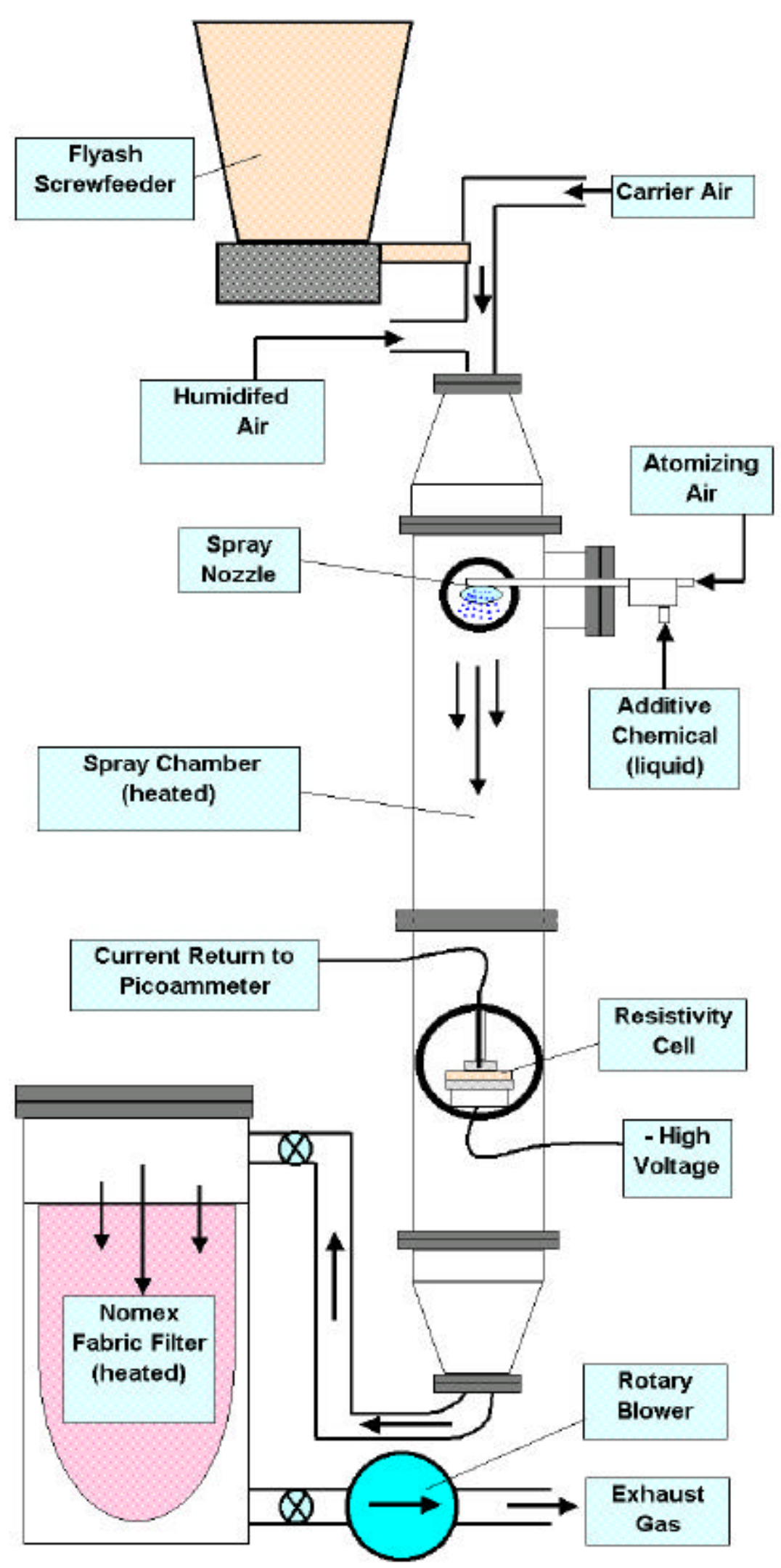

Figure 2: ADA-ES Additives Spray Chamber 


\section{Flyash Resistivity Test Method}

Resistivity is measured in a standard IEEE test cell ${ }^{1}$. For the data described in this report, the test cell was housed in a side compartment of the Additives Spray Chamber, as shown in Figure 1. Each resistivity test consists of three phases:

1) Atomized chemical and flyash are injected into the Additives Spray Chamber at a controlled feed rate, temperature, and humidity, as described above. The flyash and additive are intimately mixed and collected on a Nomex filter bag downstream of the spray chamber.

2) Conditioned ash on the filter is redistributed onto the resistivity test cell, set back in a side compartment of the chamber, and re-exposed to hot, moist gas.

3) Once the ash sample is re-equilibrated to constant temperature and humidity, an ascending V/I curve is run. This is repeated for each higher temperature point.

For each test, the amount of collected flyash and the volume of chemical pumped are measured. The weight of chemical injected is determined from volume (ml. solution) and solution concentration (gm additive/ml. solution). This allows calculation of additive-to-ash weight ratio (\% ATA). For each test series, a run with only water spray is completed to establish baseline for a given humidity level and flyash.

Calculation of resistivity is as follows ${ }^{1}$ :

$$
\rho=\mathrm{V} / \mathrm{I} \times \mathrm{A} / \mathrm{L} \times 10^{9} \text { nano-amperes/ampere } \times 10^{-3} \mathrm{Kv} / \text { volt }
$$

where:

$$
\begin{aligned}
& \rho=\text { Flyash resistivity }, \text { ohm-cm } \\
& \mathrm{V}=\text { applied dc voltage across flyash layer, volts } \\
& \mathrm{I}=\text { measured current, nano-amperes } \\
& \mathrm{L}=\text { layer thickness, } \mathrm{cm} . \\
& \mathrm{A}=\text { current-measuring electrode face area, } \mathrm{cm}^{2}
\end{aligned}
$$

For the standard IEEE resistivity cell, the ash layer is leveled off at a uniform thickness of $0.5 \mathrm{~cm}$. The diameter of the flat, circular top electrode is $2.54 \mathrm{~cm}$. The "cell factor" $\mathrm{A} / \mathrm{L}$ is:

$$
\begin{aligned}
\mathrm{A} / \mathrm{L} & =\pi \times(2.54 \mathrm{~cm} .)^{2} / 4 \times(1 / 0.5 \mathrm{~cm} .) \\
& =10.13 \mathrm{~cm} .
\end{aligned}
$$

Substituting, $\rho=\mathrm{V} / \mathrm{I} \times 10.13 \times 10^{9}$ nano-amperes/ampere 


\section{Upgrade To Laboratory Test Fixtures}

Flyash resistivity is a fundamental measurement for all laboratory tests on the project. In the next stage of the project, the resistivity tests will be conducted in a special muffle furnace with multiple test cells. By running the resistivity in a separate furnace, the Additives Spray Chamber can be devoted exclusively to sample preparation and conditioning. This arrangement will allow duplicate resistivity tests with the same ash sample. Other flyash lab tests, including ash cohesivity, will also be conducted off-line with split samples from the filter bag catch. Preliminary design of the new resistivity apparatus, as well as upgrades to the Additives Spray Chamber were commenced during the quarter.

\section{Cohesivity Test Methods}

Cohesion or adhesion of the flyash on the ESP collection plates is another fundamental ash property that affects performance. Cohesivity of dust layers is traditionally difficult to quantify in a laboratory setting and it is often evaluated only qualitatively. For purposes of this project, however, a repeatable, quantifiable measurement of dust cohesion is essential. One of the first tasks for this project was to review available methods to measure flyash cohesivity. Table 2 summarizes several methods and available instruments that were considered.

Table 2: Cohesivity Test Methods

\begin{tabular}{|l|l|l|l|}
\hline \multicolumn{1}{|c|}{ Method } & Measurement & \multicolumn{1}{c|}{ Advantages } & \multicolumn{1}{c|}{ Disadvantages } \\
\hline $\begin{array}{l}\text { Ring Shear } \\
\text { (Jenike, other) }\end{array}$ & $\begin{array}{l}\text { Measures } \\
\text { horizontal shear } \\
\text { strength of dust } \\
\text { layer }\end{array}$ & $\begin{array}{l}\text { Most widely used } \\
\text { powder test method }\end{array}$ & $\begin{array}{l}\text { Time consuming } \\
\text { Requires sample } \\
\text { preparation }\end{array}$ \\
\hline $\begin{array}{l}\text { Hosokawa } \\
\text { Micron } \\
\text { Cohetester }\end{array}$ & $\begin{array}{l}\text { Horizontal } \\
\text { tensile strength } \\
\text { of powder layer }\end{array}$ & $\begin{array}{l}\text { Simultaneously } \\
\text { measures displacement } \\
\text { of bed and cohesive } \\
\text { force }\end{array}$ & $\begin{array}{l}\text { Requires layer } \\
\text { compaction } \\
\text { Measurement at } \\
\text { ambient moisture and } \\
\text { temperature } \\
\text { Electrostatic forces not } \\
\text { involved }\end{array}$ \\
\hline $\begin{array}{l}\text { Electrostatic } \\
\text { Tensiometer }\end{array}$ & $\begin{array}{l}\text { Measures } \\
\text { electrical } \\
\text { potential at dust } \\
\text { layer } \\
\text { mechanical, } \\
\text { equates to } \\
\text { tensile strength }\end{array}$ & $\begin{array}{l}\text { Most realistic method for } \\
\text { ESP's, } \\
\text { Incorporates electrostatic } \\
\text { forces } \\
\text { Applicable to uncom- } \\
\text { pacted dust layers }\end{array}$ & $\begin{array}{l}\text { Not widely used } \\
\text { Tensile strength low } \\
\text { compared to other } \\
\text { methods }\end{array}$ \\
\hline
\end{tabular}




\begin{tabular}{|c|c|c|c|}
\hline $\begin{array}{l}\text { Powder } \\
\text { Flowability by } \\
\text { FLODEX } \\
\text { Tester }^{7}\end{array}$ & $\begin{array}{l}\text { Relative flow } \\
\text { index through } \\
\text { sized, calibrated } \\
\text { orifices }\end{array}$ & $\begin{array}{l}\text { Simple, inexpensive } \\
\text { Applicable to } \\
\text { uncompacted powder } \\
\text { samples }\end{array}$ & $\begin{array}{l}\text { Measures only relative } \\
\text { flow } \\
\text { Measurement at } \\
\text { ambient moisture and } \\
\text { temperature }\end{array}$ \\
\hline
\end{tabular}

For purposes of comparing cohesivity conditioning in an electrostatic precipitator, it was determined that the electrostatic tensiometer method offers significant advantages over the more traditional methods. The relative difference between conditioned dust layers measured at process temperature, humidity, and with an applied electrical field strength is most important in this application; absolute tensile strength and shear properties are of secondary importance. In addition, the electrostatic tensiometer method does not require sample preparation and compaction, thereby eliminating operator technique from the measurement. Finally, this method can be further applied during the full-scale trials to help quantify overall holding force. During the next quarter work will be underway to develop a bench-mounted electrostatic tensiometer. 


\section{RESULTS AND DISCUSSION}

\section{Flyash Resistivity}

A cohesivity additive will typically be applied in combination with a strong resistivitymodifying chemical, particularly for plants switching to low-sulfur coals. Therefore, one of the first research tasks of this project was to identify "base" chemicals that can be economically and effectively applied to control high resistivity. Once these are defined, cohesivity chemicals can be selected that will be chemically and physically compatible.

A series of flyash resistivity tests was conducted with a family of common deliquescent salts to evaluate suitability for application as a base resistivity additive. These were selected based on wide-scale availability, low bulk pricing, ease of handling, low toxicity, and probable compatibility with cohesivity chemicals. Results for the two best candidates, referred to as 'A' and 'B', are shown in Figure 2. Numerous tests with related chemicals from the same general family were also conducted.

As seen in Figure 1, resistivity is lowered by almost two orders of magnitude for both chemicals. The chemicals were purposely over-applied, at a rate of $0.5-0.6 \%$ additiveto-ash (ATA), to accentuate the response. The ascending temperature resistivity curve was continued to above $425^{\circ} \mathrm{C}\left(800^{\circ} \mathrm{F}\right)$, well above the thermal decomposition point of both of the trial additive chemicals.

The flyash samples were conditioned in the Additives Spray Chamber, as previously described. Flyash for all tests was a common Powder River Basin (PRB) flyash, Black Thunder, from a midwestern tangentially fired boiler. The flue gas stream consisted of humidified air at constant $10 \%$ moisture by volume. Resistivity was then measured on an ascending temperature profile over a range of $120-480^{\circ} \mathrm{C}\left(250-900^{\circ} \mathrm{F}\right)$. Several points of descending resistivity/temperature were also taken to establish the change in conditioning effect when the flyash was heated above thermal decomposition of the pure chemicals. As can be seen, the effect on resistivity disappears for both chemicals after exposure to extremely high temperatures.

In a full-scale application, the flyash resistivity would typically need to be reduced no more than a single order of magnitude. Therefore, the chemical used will be significantly less than that for these tests. Further tests at lower rates will be conducted to fully characterize these two candidate base chemicals. However, given the excellent preliminary response at this application rate, the chemicals are already expected to be cost-competitive for cold-side ESP FGC applications.

Results of an additional test conducted with Compound ' $\mathrm{B}$ ' on a low-sulfur subbituminous flyash are shown in Figure 3. Here, moisture content in the Additives Spray Chamber was maintained at a constant $10 \%$ by volume during the conditioning phase of the test and during an ascending and descending resistivity profile of the conditioned ash. However, at a temperature of $300^{\circ} \mathrm{F}$ on the descending profile, the tank heater of the humidifier water bath failed. As a result, the moisture content of the carrier gas rapidly 
dropped to around $1-2 \%$ by volume. After allowing the sample to re-equilibrate at this condition, a final resistivity measurement was taken at $125^{\circ} \mathrm{C}\left(260^{\circ} \mathrm{F}\right)$. As can be seen the measured resistivity increased sharply. This example offers some insight into the conditioning mechanism with this class of deliquescent salts; carrier gas moisture obviously plays an important role.

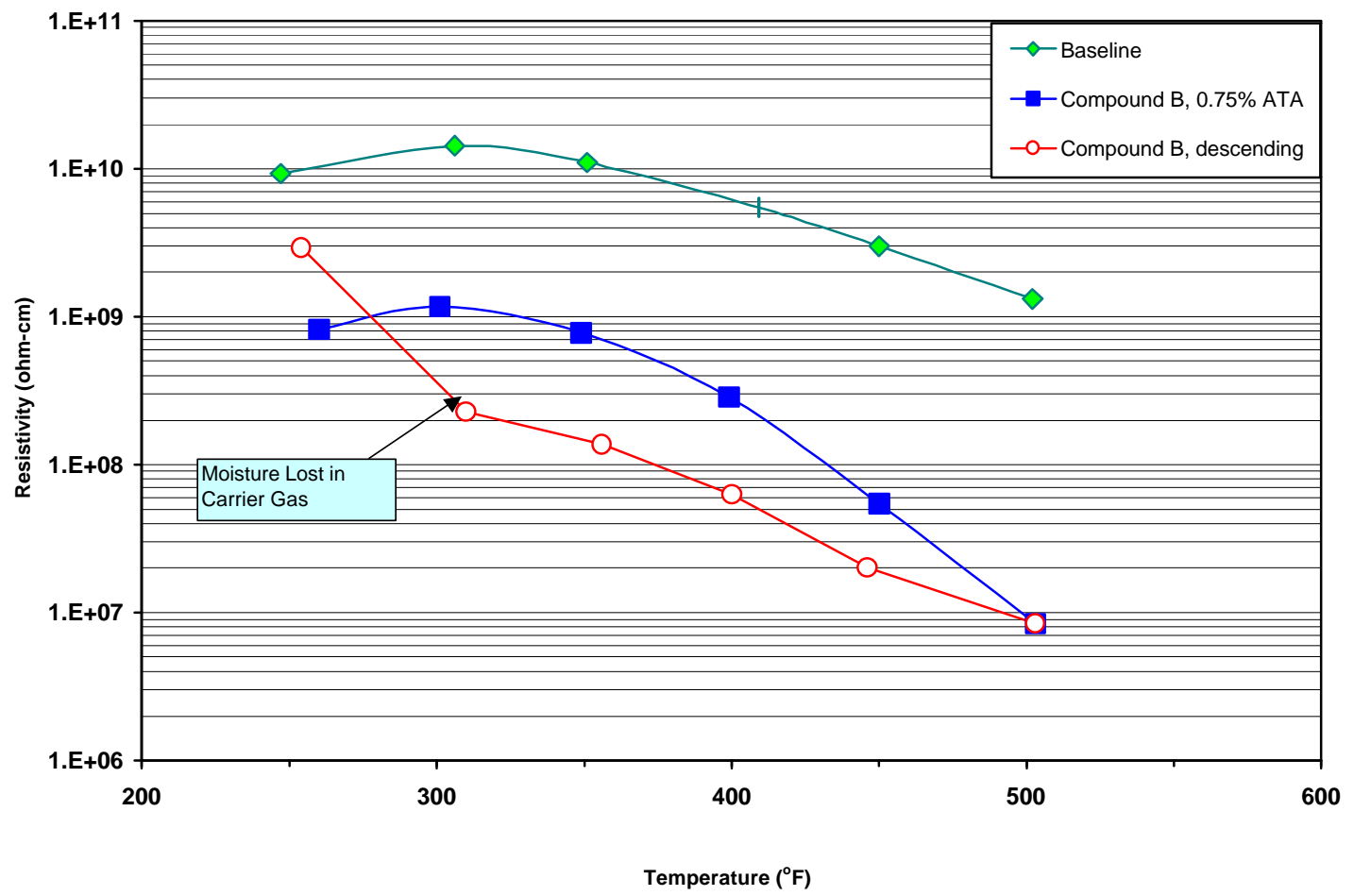

Figure 3: Effect of Moisture Loss On Flyash Resistivity with Additive Chemical 'B'

\section{Selecting Candidate Additives}

ADA-ES has contracted with Dr. David Hyatt to be a consultant to the project. He will assist in identifying potential chemical compounds and develop mechanisms associated with producing cohesive ash. Dr. Hyatt is a senior lecturer in industrial chemistry and assistant dean in the School of Natural Sciences and Mathematics at the University of Texas, Dallas. Before joining the chemistry department at UTD, he spent 30 years in industrial chemistry research, specializing in inorganic and organometallic chemicals and process development in the minerals processing industry. He received an A.B. degree from Colgate University and an M.S. and Ph.D. from the University of Illinois, UrbanaChampaign. Dr. Hyatt will be providing ongoing support to the project. His initial efforts include the identification of a suite of materials that theory suggests may produce a desirable cohesive effect. 


\section{Theoretical Considerations}

A number of mechanisms can play a role in making particles cohesive. These include the application of a naturally "sticky" material to the surface of fly ash particles, causing a chemical reaction to take place with the fly ash that produces a material exhibiting the desired cohesive properties, applying a material that utilizes other constituents from the gas stream to form a desirable property, and altering the gas stream in such a way to cause desirable secondary reactions. These and other mechanisms may act alone or in combination to produce sticky cohesive surfaces on fly ash particles.

Adhesion mechanisms can apply to particles interacting with other particles or to particles interacting with a collection surface. Inherently sticky materials can be used to bond particles together and form larger, more stable agglomerates. Agglomeration tends to produce a more cohesive dust layer on the collection surface that resists re-entrainment (particles falling off the collection surface and re-entering the gas stream).

Inherently sticky materials include sugars, carbohydrates, dextrines and starches. Most of these materials are water-soluble and can be conveyed easily using conventional spray technology. These materials are reasonably available in various grades through commodity markets. Chemical and thermal stability within the flue gas environment are possible detriments to effective use. Current large-scale industrial uses (non-food) of these types of materials are in paper and board manufactured products. Agricultural sources of the raw materials for these compounds are corn, potatoes, cane, beets and wheat.

A family of manufactured materials that exhibit sticky and binding properties include glues, gums, waxes, adhesives and resins. Bonds formed with these materials can be either chemical or mechanical in nature and can range from being very brittle to elastic. Common compounds used in formulating these materials are phenol-formaldehyde, neoprene and nitrile rubber, polyvinyl butyral, silicates, gelatins, cellulose, latex, and acetates.

One of the ways to make particles sticky or to otherwise increase particle cohesion is to increase the moisture content of the particles. Particle moisture can be adsorbed to flyash surfaces. The form of the adsorbed moisture depends on the relative humidity. Adsorbed moisture may form liquid bridges at high relative humidity. The formation of liquid bridges between particles has been identified as a key contributor to ash layer cohesion ${ }^{8}$. Liquid bridging is the process of forming particle cohesion through interfacial forces and capillary suction. Particles are held together by either highly mobile or highly viscous liquids. In the case of mobile liquids, the cohesive forces tend to be capillary and interfacial. In the case of viscous liquids, physical bonding of particles to the liquids is the predominant mechanism. These bridges can be formed by a variety of means, including physically contacting particles with water, humidification of a deliquescent salt, addition of a chemical additive to affect surface affinity for water, or addition of a chemical with bound moisture. 
There are a variety of chemical additives that could be applied to increase moisture content in the flyash. Possible additives for this purpose include humectants (common in the food industry), moisturizers or emolients (pharmaceutical and cosmetic industries), and hydrogels (medical and other industries). Both synthetic and naturally occurring substances can fall into these categories of compounds. A class of super-absorbent, hydrophilic polymers is another possibility to increase moisture in the fly ash.

There are a number of hydrate-forming compounds that may also serve the purpose of increasing the moisture content of ash. Alums are a common group of materials that readily form hydrates. Common alums include those formed with sodium, potassium, aluminum, calcium, magnesium, zinc and iron.

Various synthetic anionic and cationic polymers may have a role in fly ash cohesivity. Previous applications of polymers for flue gas conditioning have focused primarily on resistivity modification. However, there are numerous applications of polymers that depend on properties that may improve fly ash cohesion. In particular, high molecular weight temperature-stable polyacrylamide (PAM) salts, which are widely used for viscosification and flocculation of clay minerals, are possible candidates.

PAM is a water-soluble polymer that has low toxicity, although the monomer is highly neurotoxic. PAM gives off ammonia above $250^{\circ} \mathrm{C}\left(480^{\circ} \mathrm{F}\right)$. PAM is used in water treatment, papermaking, mineral processing, and enhanced oil recovery. In some forms it is also used to prevent soil erosion from agricultural land.

Another class of additives with potential is water-soluble methylcellulose and related compounds such as hydroxypropyl methylcellulose. Both of the compounds are made by the reaction of wood or cotton cellulose fibers with chemical reactants in the presence of a caustic soda. One unusual characteristic of these compounds is their ability to thermally gel. These compounds are used as thickeners, binders, film formers, waterretention agents, suspension aids, surfactants, lubricants, and emulsifiers in a wide variety of products.

Sodium carboxymethylcellulose is a promising material from this class of compounds. Sodium CMC has a hydroxyl group of the glucose units of the cellulose polymer chainreacted to form a carboxymethyl ether. Thus, the properties of the sodium CMC vary with the degree of substitution. Sodium CMC is the cellulose gum used on the largest scale. A large amount of inexpensive sodium CMC is used in the formation of synthetic detergents. It also provides a variety of functions for aqueous systems including thickening, rheology control and binding. The textile industry uses this compound for thickening printing pastes. Sodium CMC is used as an adhesive for wallpaper, for thickening oil well drilling muds, for manufacture of synthetic latex, and in lithographic printing. It is a stabilizer and thickener in cosmetics, an emollient in hand creams and lotions, and a foam stabilizer in bubble bath formulas. 


\section{Selection Process}

The candidate additives will be evaluated in the laboratory using a test fixture designed specifically for evaluating particle cohesion (electrostatic tensiometer). The primary performance parameters will be tensile strength and cohesivity as measured at the point of ash layer failure under high voltage electrostatic stress. Testing will be conducted over a range of operating temperatures 105 to $220^{\circ} \mathrm{C}\left(220\right.$ to $\left.400{ }^{\circ} \mathrm{F}\right)$, with applied electric field strength and gas moisture near actual conditions, and with fly ash from at least two coal sources; one high in alkaline constituents, like a PRB coal, one that has more acidic properties of an Eastern low sulfur coal with high silica and alumina content.

Baseline data of the fly ash will be obtained with no conditioning. A second set of data will be obtained while conditioning with $\mathrm{NH}_{3}$ and $\mathrm{SO}_{3}$ to compare performance with a known cohesivity modifier. The results from this first phase of screening will be based on changes in cohesivity and how these changes compare to those obtained with known cohesivity modifiers.

The most promising of the additives will then be put through a more extensive set of parametric screening tests. The parameters of interest in this series includes:

- Sensitivity of additive concentration to cohesivity;

- Sensitivity of the additive to different coal sources (several PRBs, Texas Lignite, Eastern Coal, To be determined);

- Impact of additive on fly ash mineral analysis;

- Impact of additive on key fly ash properties (concrete set time, available alkali);

- Requirements for storage;

- Requirements of injection system;

- Cost;

- Handling characteristics:

- Solubility;

- Freeze protection required;

- Transportation and worker safety;

- Inherent hazards (flammability, volatility, carcinogenicity).

- Fate of end products (air, water, and solids). 


\section{CONCLUSION}

In the first reporting quarter of this project, a class of common deliquescent salts was identified as a candidate "base" FGC additive for resistivity modification. Test with a sub-bituminous and a PRB coal flyash were very successful. These chemicals are watersoluble and they are widely available as bulk commodity products. Based on this finding, the trial cohesivity additives will be selected to be compatible with these chemicals. In addition, the dependence of the resistivity on moisture content in the flue gas with these conditioners suggests that they may be attracting moisture to the flyash by themselves; therefore they will also be evaluated as cohesivity chemicals.

A laboratory method to evaluate flyash cohesivity was selected. It is an experimental technique known as an electrostatic tensiometer. This method is based on measuring the point of mechanical failure of a flyash layer subjected to increasing electrical repulsion; this point is identified as the reference tensile strength. The sample is heated and humidified in an environmental chamber and subjected to an electric field equivalent to that in an actual ESP with industry-standard plate spacing. Therefore, it is a more realistic measurement of the behavior of flyash in an ESP than other methods such as ring shear testing that measure tensile strength at ambient temperature and humidity.

For the target market of undersized ESPs on older generating units that typically have higher ESP face velocities, re-entrainment is a major contributor to poor performance. Therefore, the ability to control flyash cohesivity is essential for any new flue gas conditioning additives. There are numerous possible chemicals that could be applied as liquid additives using in-situ spray atomization. A list of candidate chemical classes has been developed; the most common of these will be screened in the laboratory. 


\section{REFERENCES:}

1. IEEE Standard 548- 1984; IEEE Standard Criteria and Guidelines For the Laboratory Measurement and Reporting of Fly Ash Resistivity, 1984.

2. Jenike, A.W. "Flow Properties of Bulk Solids" American Society For Testing Materials, Proceedings, vol. 60, pp.1168 - 1190, 1960.

3. Schulze, D. "A New Ring Shear Tester For Flowability and time Consolidation Measurements" in Proceedings $1^{\text {st }}$. International Particle Technology Forum, 1994.

4. Hosokawa Micron Cohetester product literature

5. Pontius, D. and Snyder, T., "Measurement of the Tensile Strength of Uncompacted Dust Aggregates" in Powder Technology, 1991, pg. 159 -162.

6. Method And Apparatus For Measuring The Tensile Strength of Powders; US Patent Number 5,386,731, D. Pontius and T. Snyder assigned to Southern Research Institute, 1995.

7. A. Gioia, "Intrinsic flowability: a new technology for powder-flowability classification", FLODEX Technical Bulletin, Hanson Research Corporation, in Pharmaceutical Technology, Feb. 1980.

8. Snyder, T. and Vann Bush, P. "Fundamental Mechanisms in Flue Gas Conditioning", U.S. Dept. of Energy, Pittsburgh Energy Technology Center, Contract DE-AC22-91P90365. 


\section{LIST OF ACRONYMS AND ABBREVIATIONS}

ATA - Additive-to ash weight ratio, \%

CMC - Carboxymethylcellulose

$\mathrm{D}_{\max }$ - Maximum spray droplet physical diameter, microns

DOE - U.S. Department of Energy

ESP - Electrostatic Precipitator

FGC - Flue gas conditioning for particulate control

IEEE - Institute of Electrical and Electronic Engineers

PAM - Polyacrylamide polymer

PM - Particulate matter

PRB - Powder River Basin coals and resulting flyash

V/I - Voltage/current 